\title{
Erratum to: An Eye for an Eye Will Make the Whole World Blind: Conflict Escalation into Workplace Bullying and the Role of Distributive Conflict Behavior
}

Elfi Baillien ${ }^{1} \cdot$ Jeroen Camps $^{2} \cdot$ Anja Van den Broeck $^{1} \cdot$ Jeroen Stouten $^{2}$ • Lode Godderis $^{3} \cdot$ Maarten Sercu $^{3} \cdot$ Hans De Witte ${ }^{2,4}$

Published online: 1 August 2015

(C) Springer Science+Business Media Dordrecht 2015

\section{Erratum to: J Bus Ethics}

\section{DOI 10.1007/s10551-015-2563-y}

The following acknowledgment should be added to the above mentioned article.
The second author, Jeroen Camps, is a doctoral fellow of the Agency for Innovation by Science and Technology in Flanders (IWT).

The online version of the original article can be found under doi:10.1007/s10551-015-2563-y.

Elfi Baillien

elfi.baillien@kuleuven.be

$1 \quad$ Human Relations Research Group, KU Leuven, Campus

Brussels, Warmoesberg 26, 1000 Brussels, Belgium

2 Research Group Work, Organisational and Personnel Psychology, KU Leuven, Leuven, Belgium

3 IDEWE, External Service for Prevention and Protection at work, Heverlee, Belgium

4 North West University, Vanderbijlpark Campus, Vanderbijlpark, South-Africa 